\title{
PELATIHAN PEMBUATAN BAHAN AJAR DIGITAL MENGGUNAKAN APLIKASI KVSOFT FLIPBOOK DAN WEB ANYFLIP DI SMP NEGERI 41 PADANG
}

\author{
1) Widya, ${ }^{2)}$ Zaturrahmi, 3) Desy Eka Muliani, ${ }^{4)}$ Ena Suma Indrawati, 5) Yusmanila, ${ }^{6}$ Yeni Nurpatri \\ 1,2,3,4,5,6) Program Studi Pendidikan Fisika, Sekolah Tinggi Keguruan dan Ilmu Pendidikan (STKIP) Adzkia \\ E-Mail : widya@stkipadzkia.ac.id
}

\begin{abstract}
ABSTRAK
Perkembangan teknologi telah membawa perubahan di bidang pendidikan. salah satu perubahan tersebut adalah penyediaan bahan ajar digital untuk mendukung pembelajaran online. Guru sebagai fasilitator dalam pendidikan perlu beradaptasi dengan perubahan tersebut. SMP Negeri 41 Padang memandang bahwa perlu ada peningkatan kemampuan guru dalam menyiapkan bahan ajar, khususnya dalam bentuk bahan ajar digital. Oleh karena itu, tim dari program studi pendidikan fisika STKIP Adzkia melakukan pengabdian kepada masyarakat dalam bentuk pelatihan pembutan bahan ajar digital menggunakan aplikasi kvsoft flipbook dan web anyflip kepada guru-guru SMP Negeri 41 Padang. Kegiatan pengabdian yang telah dilakukan kepada guru-guru SMP Negeri 41 Kota Padang berupa pelatihan pengembangan Bahan Ajar Digital menggunakan aplikasi flipbook dan wb anyflip. Pelatihan ini memberikan dampak yang besar kepada guru dalam menyiapkan bahan ajar digital sebagai salah satu alternatif dalam penyediaan bahan ajar. Pelatihan ini mendapatkan respon baik dari pihak sekolah, baik kepala sekolah maupun majelis guru. Kepala Sekolah menyambut baik kegiatan ini, karena melalui kegiatan ini dapat meningkatkan kemampuan guru dalam menyiapkan bahan yang berkualitas dan sesuai dengan tuntutan zaman. Guru-guru juga merasa sangat terbantu dalam menyiapkan bahan ajar melalui pelatihan ini.
\end{abstract}

Kata Kunci: flipbook, anyflip, bahan ajar, digital

\section{ABSTRACT}

Technological developments have brought changes in the field of education. One of these changes is the provision of digital teaching materials to support online learning. Teachers as facilitators in education need to adapt to these changes. SMP Negeri 41 Padang views that there needs to be an increase in the ability of teachers to prepare teaching materials, especially in the form of digital teaching materials. Therefore, the team from physics education of STKIP Adzkia carried out community service in the form of training on making digital teaching materials using the kvsoft flipbook application and anyflip web for teachers of SMP Negeri 41 Padang. The service activities carried out for the teachers of SMP Negeri 41 Padang City are in the form of training on the development of Digital Teaching Materials using the flipbook and wb anyflip applications. This training has a significant impact on teachers in preparing digital teaching materials to provide teaching materials. This training received a good response from the school, both the principal and the teacher council. The principal welcomes this activity because this activity can improve teachers' ability to prepare quality materials and the times' demands. The teachers also found it very helpful in preparing teaching materials through this training.

Keyword: flipbook, anyflip, learning materials, digital

\section{PENDAHULUAN}

\section{Latar Belakang}

SMP Negeri 41 Padang merupakan salah satu SMP termuda di Kota Padang. SMP Negeri 41 Padang baru memulai operasional pada tahun akademik 2017[1]. Awalnya SMP ini merupakan Filial dari SMP Negeri lain yang ada di Kota Padang. Akreditasi SMP Negeri 41 Padang sejak tahun 2019 adalah C. Adapun data umum tentang SMP Negeri 41 Padang disajikan pada gambar berikut: 


\section{Fi: SEKOLAH KITA}

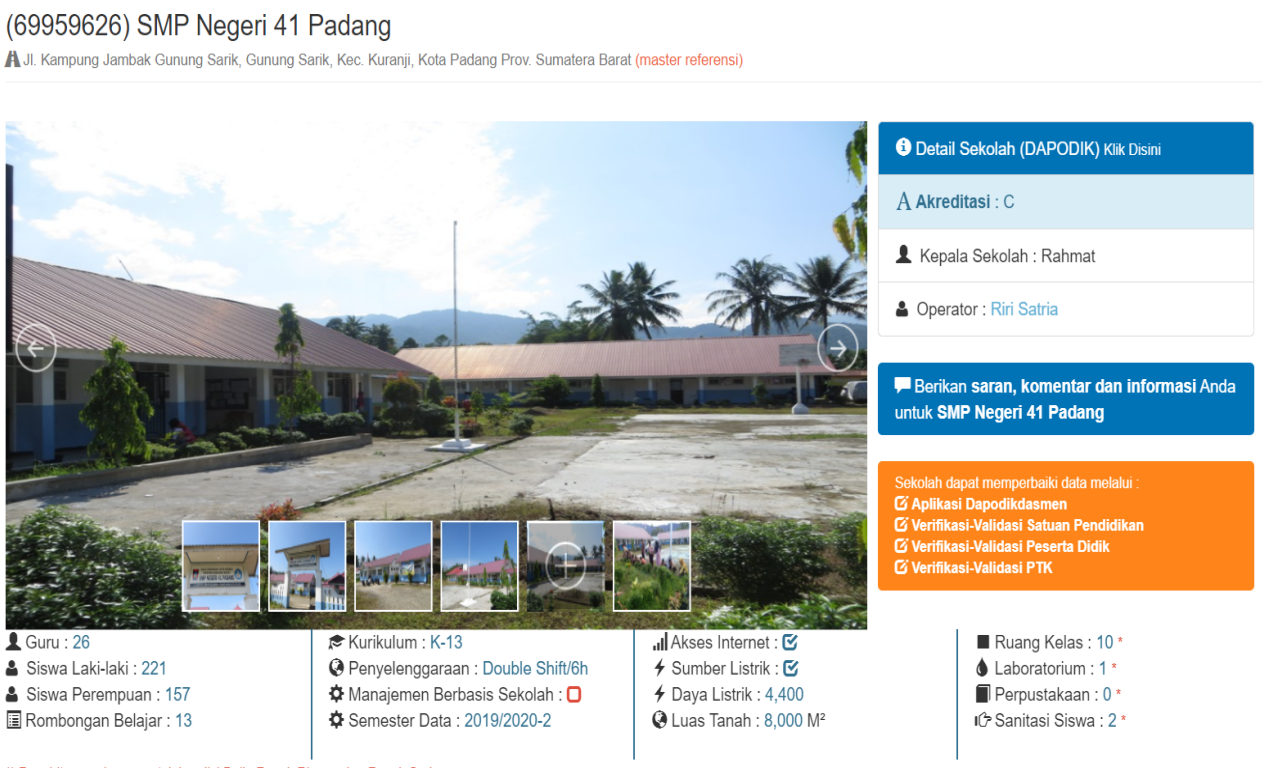

Gambar 1: Data Umum tentang SMP Negeri 41 Padang

Gambar di atas memuat informasi bahwa SMP Negeri 41 Padang secara kualitas masih di bawah rata-rata. Akreditasi sekolah berada pada kategori C, sarana dan prasarana belum cukup (perpustakaan belum ada dan laboratorium baru 1 unit). Namun di sisi lain, SMP Negeri 41 Padang memiliki rasio jumlah guru dan siswa yang baik 1: 14.5. Hal ini merupakan potensi yang dimiliki oleh SMP Negeri 41 Padang untuk dapat memberikan kualitas layanan baik kepada siswa. Berkenaan dengan kulaitas dan kuantitas sarana dan prasrana, SMP Negeri 41 Padang belum memiliki sarana labor untuk pembelajaran langsung yang memadai untuk terciptanya suasana belajar yang berkualitas dan menyenangkankan untuk siswa. Untuk mengatasi kelemahan kualitas sarana berupa labor di atas, SMP Negeri 41 Padang mempunyai kesempatan untuk mengembangkan Bahan Ajar Digital yang bermuatan materi interaktif dan virtual laboratory, yang bisa diakses oleh siswa dimanapun berada. rangka meningkatkan kualitas pembelajaran yang ada saat ini. Salah satu langkah yang dapat diambil adalah menyediakan bahan ajar digital, yang bisa diakses oleh seluruh siswa dimana saja dan kapan saja.

Kota Padang merupakan kota dengan kualitas jaringan yang hampir baik untuk semua provider, jadi masalah koneksi jaringan hampir tidak akan ditemui jika guru menggunakan bahan ajar digital. Saat ini hampir seluruh siswa sudah menggunakan smartphone. $58 \%$ dari jumlah pengguna smarphone di Indonesia didominasi oleh remaja umur 12- 20 tahun [2]. Hal ini merupakan tantangan bagi guru dalam menyiapkan bahan ajar dalam bentuk digital, bahan ajar yang lebih aktual, dan materi yang disampikan oleh guru bisa dipahami dengan mudah oleh siswa. Namun, kemampuan guru dalam menyiapkan bahan ajar dalam bentuk digital masih kurang. Berdasarkan wawancara yang penulis lakukan dengan kepala sekolah SMP Negeri 41 Padang diperoleh informasi bahwa guru belum pernah mengikuti pelatihan berjangka terkait penyiapan bahan ajar digital. Guru di SMP Negeri 41 Padang menggunakan Google Class Room (GCR) untuk membagikan Pembelajaran Jarak Jauh (PJJ)/online. Bahan ajar yang dibagikan 
guru adalah video yang ada di Youtube saja, bahan ajar pdf yang sudah ada di internet sebelumnya, atau foto dari buku yang dimiliki guru. Bahan ajar yang disediakan tidak interaktif, sehingga membosankan untuk siswa. Semakin lama pembelajaran Jarak Jauh yang diberikan oleh guru menjadi membosankan dan lambat respon dari siswa. Akhirnya pembelajaran menjadi tidak bermakna dan jauh dari kualitas yang baik. Walaupun pembelajaran dilakukan jarak jauh/guru dan siswa saling tidak bertatap muka, namun interkasi antara guru dan siswa harus tetap dijaga, agar pembelajaran dua arah dapat terlaksana dengan baik[3]

Selain itu, salah satu perbedaan mendasar pembelajaran di abad 21 dengan pembelajran sebelumnya adalah penerapan teknologi dalam pembelajaran. Guru harus adaptif terhadap perubahan dan perbedaan tersebut [4]. Penggunaan teknologi merupakan sebuah keharusan dalam pembelajaran [5]. Pelatihan penggunaan teknologi dalam pembelajaran yang diberikan kepada guru sebelumnya belum banyak, karena hanya dalam bentuk pelatihan sekali pertemuan, dan tidak ada luaran yang dihasilkan dari pelatihan tersebut. Untuk itu perlu dilakukan pelatihan terjadwal dan terstrukutur dalam melatih guru untuk penyiapan bahan ajar digital, baik berupa video, animasi, soal evaluasi interaktif, dan fitur-fitur lengkap lainnya. Oleh karena itu tim pengabdian STKIP Adzkia dan pihak sekolah SMP Negeri 41 Padang bersepakat mengadakan pelatihan pembuatan bahan ajar digital. Harapan dengan adanya kegiatan ini, Guru SMP Negeri 41 Padang mampu menyediakan bahan ajar digital yang sesuai dengan pekembangan zaman dan teknologi, namun tak meninggalkan pertimbangan pada kondisi siswa dan keadaan di sekolah. Bahan ajar digital adalah segala bentuk bahan yang disiapkan dalam bentuk digital yang digunakan untuk membantu guru atau instruktur dalam melaksanakan proses pembelajaran[6]. Bahan ajar digital merupakan sebuah keharusan di saat ini[7]. Guru diharapkan mengusai beberapa aplikasi yang bisa digunakan untuk menyiapkan pembelajaran digital. Keunggulan bahan ajar digital: 1) Meningkatkan kadar interaksi pembelajaran antara peserta didik dengan guru atau instruktur, 2) Memungkinkan terjadinya interaksi pembelajaran dari mana dan kapan saja, 3) Menjangkau peserta didik dalam cakupan yang luas, 4) Mempermudah penyempurnaan dan penyimpanan materi pembelajaran[8]. Dengan adanya bahan ajar digital akan mempermudah siswa dalam mengakses bahan ajar dimanapun berada.

Bahan ajar digital merupakan sebuah keharusan dalam pembelajaran di abad 21[9]. Pembelajaran digital memenuhi kriteria sebagai berikut: terdapat interaksi guru dan siswa, sumber belajar tidak terbatas, berisi media online sehingga dapat dengan mudah diakses dan diunduh oleh siswa[6]. Guru diharapkan mampu beradaptasi dan belajar dengan cepat terkait penyediaan bahan ajar digital. Kepala SMP Negeri 41 Padang berkomitmen untuk meningkatkan kapasitas guru dalam menyediakan bahan ajar. Hal ini dilakukan untuk meningkatkan kualitas pembelajaran dan berdampak jangka panjang pada akreditasi SMP Negeri 41 Padang nantinya. Pelatihan dan pendampingan akan dilakukan oleh Tim Pengabdian Masyarakat (Widya, M.Pd., Ena Suma Indrawati, M.Pd., Zaturrahmi, M.Pd, Desy Eka Muliani, M.Pd., Yeni Nurpatri, M.Pd., dan Yusmanila, M.Pd).

Saat ini banyak tersedia aplikasi yang bisa digunakan untuk mengembangkan bahan ajar digital. Salah satunya adalah kvsoft flipbook maker dan web anyflip. Aplikasi ini memungkinkan guru membuat bahan ajar digital yang memuat video, animasi, audio, dan lainnya[10]. Sedangkan web anyflip, merupakan web gratis dan membayar untuk membuat flipbook secara online[11]. Aplikasi kvsoft flipbook maker memiliki keunggulan dapat melampirkan audio maupun video 
walaupun menggunakan aplikasi gratis, namun produk aplikasi ini harus dalam bentuk format . exe, yang tidak bisa dibuka di smartphone. Web anyflip memiliki keunggulan dapat dibagikan dengan mudah ke semua siswa melalui link, siswa bisa mengakses dimanapun, namun aplikasi ini tidak bisa memuat video atau audio untuk akun yang gratis.

\section{METODE PELAKSANAAN}

Berikut ini disajikan langkah yang dilakukan pada pengabdian masyarakat pelatihan pembuatan bahan ajar digital di SMP Negeri 41 Padang:

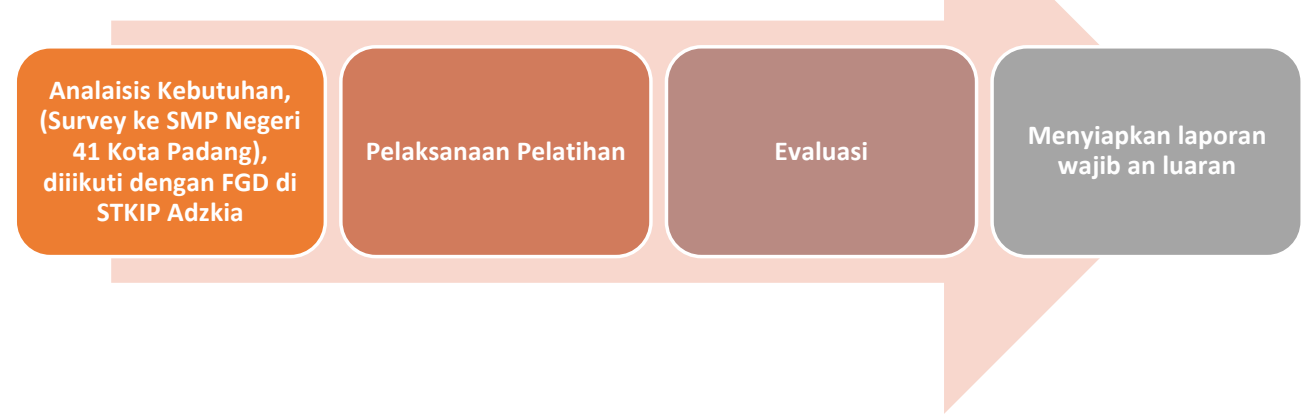

\section{Gambar 2: Alur Pelaksanaan Pengabdian Masyarakat}

Adapun tahapan yang akan dilakukan oleh tim pengabdian masyarakat adalah:

1. Survey kondisi di SMP Negeri 41 Padang untuk menganalisis pelatihan yang dibutuhkan oleh Mitra (SMP Negeri 41 Padang).

2. Melakukan Focus Group Discusion di STKIP Adzkia dengan mengundang pihak terkait, dan meminta saran-saran pihak terkait untuk perbaikan rencana pengabdian masayarakat yang akan dilakukan.

3. Melakukan pelatihan sebanyak 10 pertemuan terkait pembuatan bahan ajar digital dengan agenda:

a. Pembukaan oleh Kepala SMP Negeri 41 Kota Padang.

b. Pemaparan materi "Pentingnya Bahan Ajar Digital" oleh Zaturrahmi, M.Pd.

c. Pelatihan pembuatan bahan ajar digital menggunakan "flipbook" oleh Widya, M.Pd.

4. Melakuan evaluasi kegiatan bersama tim dan kepala SMP Negeri 41 Kota Padang.

\section{HASIL}

Melalui pengabdian ini diharapkan guru SMP Negeri 41 mampu mengembangkan bahan ajar digital sebagai opsi lain dalam menyampaikan materi pembelajaran. Pelatihan dilakukan pada tanggal 16 Desember 2020 di SMP Negeri 41 Kota Padang. Pengabdian ini dihadiri oleh orang guru SMP Negeri 41 Kota Padang. Berikut ini disajikan gambar kegiatan pelatihan ini: 

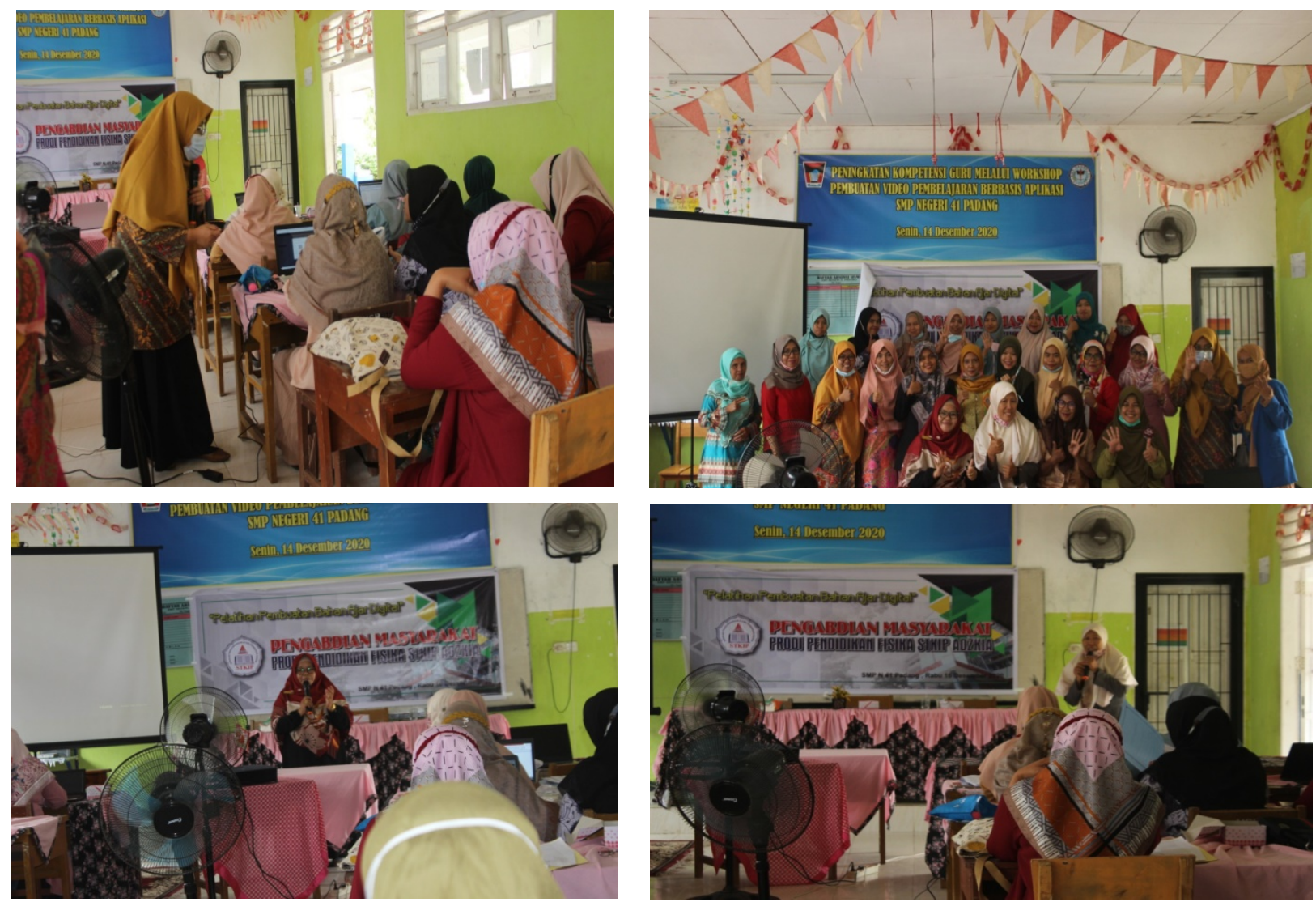

Gambar 3: Cuplikan Kegiatan Pelatihan Pembuatan Bahan Ajar Digital

Adapun materi yang disampaikan pada pelatihan bahan ajar digital adalah:

a. Pengenalan Bahan Ajar Digital

b. Perbandingan Bahan Ajar Digital dan Cetak

c. Langkah Pembuatan Bahan Ajar menggunakan aplikasi kvsoft flipbook

\section{MENGGUNAKAN APLIKASI KVISOFT}

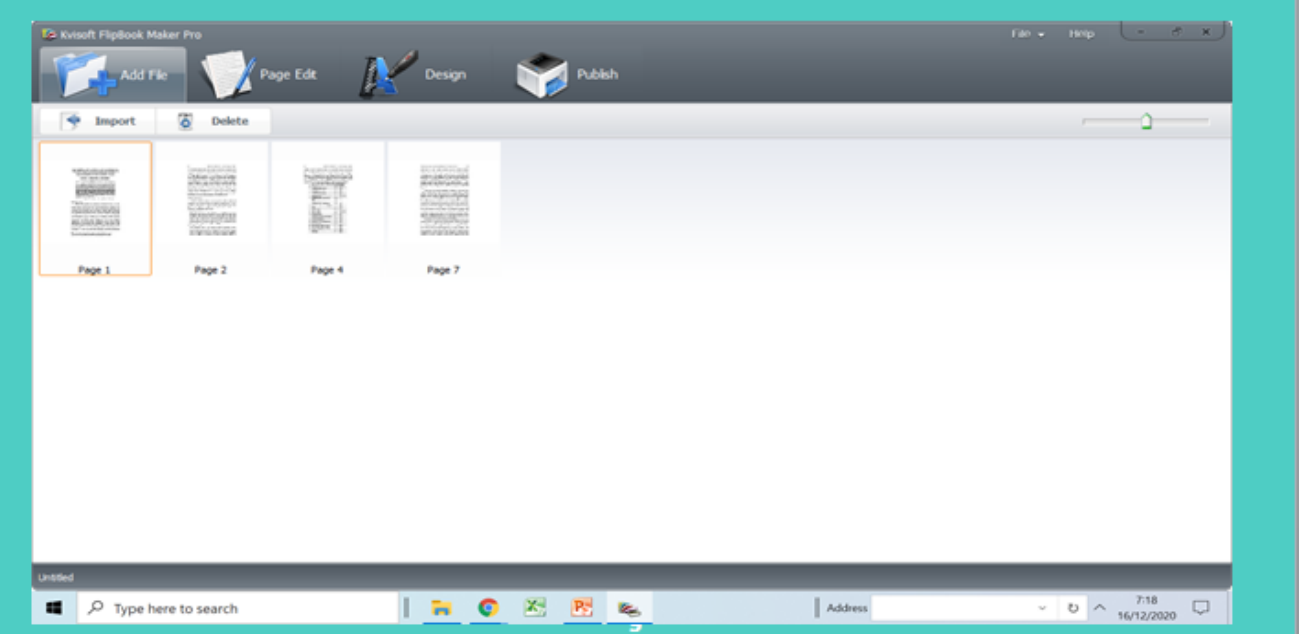

Gambar 4: Aplikasi Kvisoft 
d. Langkah Pembuatan Bahan Ajar Melalui Web: anyflip.com

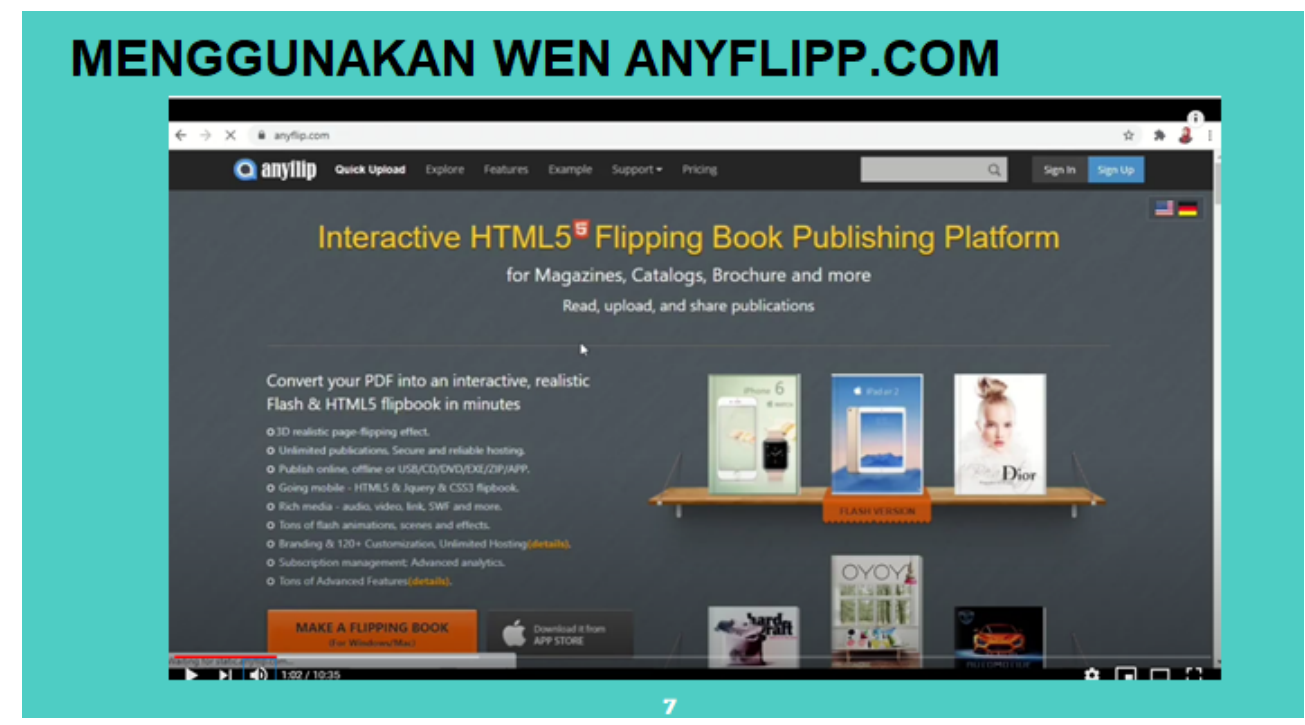

Gambar 5: Web anyflip.com

Kepala Sekolah dan Majelis Guru SMP Negeri 41 Padang sangat antusias dengan pelatihan ini. Kepala Sekolah menyatakan bahwa pelatihan ini sangat dibutuhkan oleh guru di SMP Negeri 41 Padang untuk meningkatkan kualitas bahan ajar. Kepala sekolah menyampaikan bahwa dengan tersedianya bahan ajar yang bermutu, akan meningkatkan kualitas pembelajaran, pembelajaran menjadi menyenangkan, dan diikuti dengan peningkatan tingkat ketercapaian kompetensi. Beberapa orang guru menyampaikan bahwa pengabdian ini sangat bermanfaat, menjadi salah satu solusi untuk pembelajaran daring yang sedang dilakukan oleh semua guru. Aplikasi kvsoft flipbook ataup web anyflip cukup mudah digunakan. Guru hanya perlu menyediakan bahan ajar dalam bentuk pdf, kemudian dikonversi menjadi flipbook. Tanggapan lain dari guru, bahan ajar digital yang dikembangkan melalui flipbook sangat inovatif, karena guru dapat menambahkan video dan audio di dalam buku, sehingga tampilan buku menjadi lebih menarik, interaktif, dan sangat berbeda dengan buku cetak. Guru bertekad akan membuat bahan ajar di semester berikutnya menggunakan aplikasi flipbook atau web anyflip. Guru-guru juga mengharapkan ada pelatihan sejenis dilakukan di masa mendatang untuk membantu guru beradaptasi di setiap perkembangan zaman.

\section{KESIMPULAN}

Kegiatan pengabdian yang telah dilakukan kepada guru-guru SMP Negeri 41 Kota Padang berupa pelatihan pengembangan Bahan Ajar Digital menggunakan aplikasi flipbook dan wb anyflip. Pelatihan ini memberikan dampak yang besar kepada guru dalam menyiapkan bahan ajar digital sebagai salah satu alternatif dalam penyediaan bahan ajar. Pelatihan ini mendapatkan respon baik dari pihak sekolah, baik kepala sekolah maupun majelis guru. Kepala Sekolah menyambut baik kegiatan ini, karena melalui kegiatan ini dapat meningkatkan kemampuan guru dalam menyiapkan bahan yang berkualitas dan sesuai dengan tuntutan zaman. Guru-guru juga merasa sangat terbantu dalam menyiapkan bahan ajar melalui pelatihan ini. 


\section{DAFTAR PUSTAKA}

1] "Sekolah Kita." http://sekolah.data.kemdikbud.go.id/index.php/chome/profil/7d72090ecf91-438c-9b7c-e50fb9f34773 (accessed Oct. 29, 2020).

[2] J. Nasution, N. Neviyarni, and A. Alizamar, "Motif Siswa memiliki Smartphone dan Penggunaannya," JPPI (Jurnal Penelitian Pendidikan Indonesia), vol. 3, p. 15, Dec. 2017 , doi: $10.29210 / 02017114$.

[3] "Pengembangan Bahan Ajar Digital Berlandaskan Model Guided-Project Based Learning Pengembangan Bahan Ajar Digital Berlandaskan Model Guided-Project Based Learning | Taufiqy | Jurnal Pendidikan: Teori, Penelitian, dan Pengembangan." http://journal.um.ac.id/index.php/jptpp/article/view/6228 (accessed Oct. 29, 2020).

[4] W. Widya, E. S. Indrawati, D. E. Muliani, and M. Ridhatullah, "Design of Integrated Science Learning Materials Based on Creative Problem Solving Model Integrated with Anti-Corruption Characters," Kasuari: Physics Education Journal (KPEJ), vol. 2, no. 2, Art. no. 2, Dec. 2019, doi: 10.37891/kpej.v2i2.103.

[5] I. W. Redhana, "Mengembangkan Keterampilan Abad Ke-21 Dalam Pembelajaran Kimia," Jurnal Inovasi Pendidikan Kimia, vol. 13, no. 1, Art. no. 1, Feb. 2019, Accessed: Oct. 03, 2020.

[Online].

Available:

https://journal.unnes.ac.id/nju/index.php/JIPK/article/view/17824.

[6] N. Nana and E. Surahman, "Pengembangan Inovasi Pembelajaran Digital Menggunakan Model Blended POE2WE di Era Revolusi Industri 4.0," Prosiding SNFA (Seminar Nasional Fisika dan Aplikasinya), vol. 4, no. 0, Art. no. 0, Dec. 2019, doi: 10.20961/prosidingsnfa.v4i0.35915.

[7] W. Widya, E. S. Indrawati, and D. E. Mulyani, "Preliminary Analysis Of Learning Materials Development Based On Creative Solving Model Integrated By Anticorruption Characters," Proceeding ASEAN Youth Conference, Oct. 2019, Accessed: Sep. 14, 2020. [Online]. Available: http://jurnal.aycppim.id/index.php/ayc/article/view/7.

[8] D. T. Irafahmi and E. S. Andayani, "Pengembangan Bahan Ajar Akuntansi Berbasis Komputer Untuk Smk Program Keahlian Bisnis \& Manajemen Se-Kota Malang," Journal of Accounting and Business Education, vol. 1, no. 2, Art. no. 2, Sep. 2016, doi: 10.26675/jabe.v1i2.6018.

[9] "Student Centered Learning: Alternatif Pembelajaran Inovatif Abad 21 untuk Menyiapkan Guru Profesional | Santyasa | Quantum: Seminar Nasional Fisika, dan Pendidikan Fisika." http://seminar.uad.ac.id/index.php/quantum/article/view/347 (accessed Oct. 03, 2020).

[10] "Studi Pendampingan Pengembangan Bahan Ajar Tematik Terintegrasi Literasi Baru dan Literasi Bencana Pada Guru IPA Kabupaten Agam | Jurnal Eksakta Pendidikan (JEP)." http://jep.ppj.unp.ac.id/index.php/jep/article/view/431 (accessed Oct. 29, 2020). 